\title{
Impact of Extraction Method on Physicochemical Characteristics and Antioxidant Potential of Adansonia digitata Oil
}

\author{
Mady Cissé1, Alioune Sow ${ }^{1,2^{*}}$, Patrick Poucheret ${ }^{2}$, Delphine Margout ${ }^{2}$, Nicolas Cyrille Ayessou1, \\ Papa Guédel Faye ${ }^{1}$, Mama Sakhoํㅜ , Codou Mar Gueye Diop ${ }^{1}$
}

\begin{abstract}
${ }^{1}$ Laboratoire de Formation Continue en Industries Agroalimentaire (LFCIA), ESP-UCAD, Centre d'Etudes sur la Sécurité alimentaire et les Molécules fonctionnelles (CESAM-RESCIF), ESP-UCAD, Dakar, Senegal

${ }^{2}$ UMR Qualisud Université de Montpellier, CIRAD, Montpellier Supagro, Université Avignon, Université La Réunion, Montpellier, France

Email: mady.cisse@ucad.edu.sn, aliouneabdsow@hotmail.fr, patrick.poucheret@umontpellier.fr, nayessou@yahoo.fr, guedougui@hotmail.com,mfsakho@yahoo.fr, cgmare@gmail.com, *aliouneabdsow@hotmail.fr
\end{abstract}

How to cite this paper: Cissé, M., Sow, A., Poucheret, P., Margout, D., Ayessou, N.C., Faye, P.G., Sakho, M. and Diop, C.M.G. (2018) Impact of Extraction Method on Physicochemical Characteristics and Antioxidant Potential of Adansonia digitata Oil. Food and Nutrition Sciences, 9, 937-955. https://doi.org/10.4236/fns.2018.98069

Received: June 11, 2018

Accepted: August 10, 2018

Published: August 13, 2018

Copyright $\odot 2018$ by authors and Scientific Research Publishing Inc. This work is licensed under the Creative Commons Attribution International License (CC BY 4.0).

http://creativecommons.org/licenses/by/4.0/ (c) (i) Open Access

\begin{abstract}
In this study, the effect of extraction processes on the physicochemical characteristics and antioxidant potential of baobab (Adansonia digitata L.) seed oil was evaluated. The oils were extracted, on the one hand, by cold pressing, and on the other hand, with three types of organic solvents (acetone, chloroform, $\mathrm{n}$-hexane). The recorded results indicated that the extraction yield of baobab oil was significantly impacted by both the extraction method and the polarity of the solvent used. In addition, chloroform provides the best extraction yield ( $40.12 \pm 0.607)$. However, extraction by cold pressure preserves at best the physicochemical and bioactive properties of the extracted oils. Indeed, the pressing oil contains a content of phenolic compounds (0.047 \pm $0.0024 \mathrm{mgEAG} / \mathrm{g}$ of oil) and a very high radical scavenging activity (DPPH) $(31.71 \% \pm 0.61 \%)$. For the various oils extracted, the minimum and maximum values were 0.50 and $3.17 \mathrm{mEq} \cdot \mathrm{kg}^{-1} ; 56.26$ and $99.113 \mathrm{mgI}_{2} \cdot 100 \mathrm{~g}^{-1} ; 1.457$ and 1.465; 205.37 and $233.587 \mathrm{mgKOH} / \mathrm{g}$ respectively for the peroxide, iodine, refractive and saponification values. The color parameters $\left(L^{*}, a^{*}\right.$ and $\left.b^{*}\right)$ of the oils also differ depending on the nature of the organic solvent used. Principal component analysis (PCA) and correlation analysis were performed on the physicochemical properties and the antioxidant potential of the extracted oils. Therefore, the results suggest the mixed use of acetone and hexane to obtain oil comparable to that extracted by cold pressing.
\end{abstract}

\section{Keywords}

Adansonia digitata L., Oil, Extraction, Biochemical Characteristics 


\section{Introduction}

The baobab (Adansonia digitata L.) is an emblematic tree of African savanna [1]. It is one of the most striking and recognizable woody species in Africa due to its large size [2] and can reach more than $25 \mathrm{~m}$ in height [3] [4]. The genus Adansonia belongs to the family Bombacaceae and the order Malvales [5]. In Africa, this baobab species is present only in the semi-arid and sub-humid regions south of the Sahara with the exception of Liberia, Uganda, Djibouti and Burundi [2] [6]. In Senegal, stands of Adansonia digitata L. are present throughout the country [3]. The different parts of the baobab (roots, bark, wood, gum, leaves, flowers, capsules, pulp, seeds) are used [6] [7] [8]. Buchmann et al. [7] reported about 300 traditional uses of baobab in Africa. The baobab fruit weighs between 150 and $350 \mathrm{~g}$ in Senegal, and can reach more than $496 \mathrm{~g}$ in Niger [9]. The total mass of the seeds represents between $43 \%$ and $60 \%$ of the total mass of the fruit [3] [10]. The seeds contain very high concentrations in terms of protein (18.4\%), lipids (12.2\%) and carbohydrates (45.1\%) [11]. Baobab seed oil is used in the pharmaceutical and cosmetic industries because of its content of essential fatty acids and vitamins A, D, E and F [12] [13]. Indeed, the oil allows the rejuvenation and renewal of cells, thus improving the elasticity of the skin and reducing the appearance of stretch marks [14]. It is known for its high permeability, its nourishing properties, its emollient power and its softening properties on the skin and scalp [14] [15]. Used as a massage cream, baobab oil softens the skin and helps relieve pain and injury [14]. Also, they have been used in the treatment of various conditions such as hair dandruff, muscle spasm, varicose veins and wounds [12]. Vermaak et al. [13] indicate that baobab seed oil is used alone or in combination with other parts of the plant to treat various conditions such as fever, diarrhea, cough, dysentery, hemoptysis and worms. In traditional medicine, the oil has been used to treat inflammation of the gums and to relieve toothache [6]. After the treatment of the oil, the residual part is mixed with coconut oil for the manufacture of soap which helps to fight against skin diseases such as eczema, sunburn, acne and rashes [16]. In the literature, several studies have been devoted to the characterization of oil extracted with organic solvents [17] [18] [19] [20] [21]. However, studies on the antioxidant potential of baobab oils extracted by pressing are unknown as well as comparison of baobab oils extracted by organic solvent with that of cold pressure. In this context, our study aims to evaluate, the effect of different extraction methods on the extraction yield, the physicochemical properties and the antioxidant potential of the different baobab oils. Thus, this study should provide information likely to promote, in the industrial and pharmaceutical fields, a large-scale use of baobab oil.

\section{Materialand Methods}

\subsection{Plant Material and Pretreatments}

The fruits were collected in the locality of Bignona $\left(12^{\circ} 45^{\prime} 0^{\prime \prime}\right.$ North and $16^{\circ} 30^{\prime} 0^{\prime \prime}$ 
West), Senegal. A voucher specimen are stored and referenced under a specified identification number. The pulped seeds were washed and then dried at $65^{\circ} \mathrm{C}$ for 24 hours in an oven. After drying, the seeds were crushed with a pestle and a mortar and then crushed with a hammer mill (Moulinex, AR 11). The ground product thus obtained was also sieved using a $600 \mu \mathrm{m}$ mesh sieve to obtain a finer particle size used for the extraction procedures. All analyses such as extraction and chemical parameters were made in duplicate during this work.

\subsection{Extraction of Oil by Pressing}

The extraction of the oil was carried out using a mechanical press (DD85G, IBG MonfortsOekotec $\mathrm{GmbH}$, Mönchenglabach, Germany). The $10 \mathrm{~mm}$ die was used throughout the extraction and the rotational speed of $25 \mathrm{rpm}$ was maintained. The outlet head temperature was also maintained at $105^{\circ} \mathrm{C}$ throughout the operation. Beforehand, the exit head was brought to this temperature for about 25 minutes before the start of the extraction operation. At the end of the extraction, the obtained crude baobab oil is a mixture of oil with gummy impurities. This crude oil was immediately packaged in bottles for two days for decantation. The oil was transferred to new bottles and centrifuged (centrifuge Hettich, Zentrifugen, Germany) at $4500 \mathrm{rpm}$ for 10 minutes. The obtained oil was stored at $4^{\circ} \mathrm{C}$ for later analyzes.

\subsection{Extraction of Oil by Solvent}

In this part, the baobab oil was extracted with Soxhlet on particles with particle sizes of less than $600 \mu \mathrm{m}$ using acetone, chloroform or $\mathrm{n}$-hexane. These solvents were purchased from Prolabo (VWR Chemicals, USA). During extraction of the oil, the temperature of $70^{\circ} \mathrm{C} \pm 2{ }^{\circ} \mathrm{C}$, the extraction time of six (6) hours and the ratio of $1: 8(\mathrm{~g} / \mathrm{mL})$ were used based on the optimum parameters obtained on different seeds [22] [23] [24] [25]. In order to remove traces of solvents, the extracted oil was evaporated by means of a rotary evaporator (Heidolph, Germany) at $45^{\circ} \mathrm{C}$ and then put in an oven for 24 hours at $40^{\circ} \mathrm{C}$.

\subsection{Analytical Methods}

The physicochemical characteristics of extraction oils such as density, acidity, peroxide value, acid value, refractive index, iodine value, saponification value and color index of the extracted oils were determined. The saponification value was determined according to the French standard NF T60-206; The acid value according to standard NF T60-204. The acidity which corresponds to the percentage expression of oleic acid was calculated from the acid value. The iodine value is determined according to the French standard NF T60-203; The peroxide value according to the French standard NF T60-220; The extraction yield according to the standard soxhlet extraction method (NF V03-905). The density was measured by the NF T60-214 method at $25^{\circ} \mathrm{C}$. The polyphenols were assayed according to the method of Georgé et al. [26]. The 
extinction coefficients at $232 \mathrm{~nm}$ and $270 \mathrm{~nm}\left(\mathrm{k}_{232}\right.$ and $\left.\mathrm{k}_{270}\right)$ were determined according to the French standard NF T60-223 with a UV spectrophotometer (SPECORD 200 PLUS). The refractive index was measured with a refractometer (EXACTA-OPTECH, Mod-RMT, München, Germany). A colorimeter (CM-5, Konica Minolta Sensing Americas Inc., US) was used to determine the $L^{*}, a^{*}, b^{*}$, $\mathrm{Y} 1, \mathrm{c}^{\star}$ and $\mathrm{h}$ color parameters of the various oils. The component $\mathrm{L}^{\star}$ indicating the clarity or luminance varies from black to white. The component $a^{*}$ corresponds to the green-red antagonist couple. The component $\mathrm{b}^{\star}$ corresponds to the blue-yellow antagonistic couple; $\mathrm{Y} 1, \mathrm{c}^{*}$ and $\mathrm{h}$ correspond respectively to the yellowingindex, chromaticity and chromatic tone.

\subsection{Antioxidant Activity}

The antioxidant activity was evaluated with 2.2-diphenyl-1-pyridyrazyl (DPPH) according to the method described by Adaramola et al. [27]. In addition, some adjustments were made to its protocol. Thus, $2 \mathrm{~mL}$ of DPPH $(0.1 \mathrm{mM})$ prepared in methanol was introduced into a test tube containing $0.5 \mathrm{~mL}$ of baobab oil. The mixture was stirred for five (5) minutes and then incubated in the dark and at room temperature for 30 minutes. After this incubation period, the absorbance was read at $517 \mathrm{~nm}$ against a blank $(0.5 \mathrm{~mL}$ of baobab oil and $2 \mathrm{~mL}$ of methanol) using a UV spectrophotometer (SPECORD 200 PLUS). The absorbance of the control $(0.5 \mathrm{~mL}$ of DPPH and $2 \mathrm{~mL}$ of methanol) is determined at this wavelength. This activity is compared to a control antioxidant (quercetin). The antiradical activity is expressed as a percentage of DPPH reduced according to this relation:

$$
\text { Inhibition of DPPH }(\%)=\frac{\text { Absorbance }_{\text {control }}-\text { Absorbance }_{\text {sample }}}{\text { Absorbance }_{\text {control }}} \times 100
$$

\subsection{Statistical Analysis}

A principal component analysis (PCA) and a hierarchical classification were carried out on the physicochemical data of the oils in order to find the best correlations between the random variables. The results obtained have been studied by correlation analyzes (Pearson correlation coefficients) between the physicochemical properties and the antioxidant potential of the extracted oils. To compare the averages, this analyzes of variance with the Fisher LSD test at the significance level of 5\% were also performed. Thus, all analyzes were carried out with software R (version 3.2.4, 2016).

\section{Results and Discussion}

\subsection{Physical Properties}

The physical parameters studied on the various oils of baobab include the extraction yield, the density, the refractive index, the extinction coefficients and the color indices. The results obtained are listed in Table 1 . 
Table 1. Physicochemical characteristics of baobab oils extracted by cold pressing and organic solvents.

\begin{tabular}{|c|c|c|c|c|}
\hline Parameters & Pressure & Acetone & Chloroform & n-Hexane \\
\hline Oilyield (\%) & $6.280 \pm 0.432^{\mathrm{a}}$ & $23.05 \pm 0.614^{\mathrm{b}}$ & $40.12 \pm 0.607^{\mathrm{d}}$ & $30.29 \pm 0.521^{c}$ \\
\hline Density & $0.911 \pm 0.04^{\mathrm{b}}$ & $0.882 \pm 0.016^{\mathrm{a}}$ & $0.945 \pm 0.013^{c}$ & $0.902 \pm 0.020^{\mathrm{ab}}$ \\
\hline Refractive index & $1.464 \pm 2.8 \cdot 10^{-4 b}$ & $1.459 \pm 3.10^{-4 \mathrm{a}}$ & $1.457 \pm 3.10^{-4 a}$ & $1.465 \pm 3.10^{-4 b}$ \\
\hline $\begin{array}{l}\text { Iodine value } \\
\left(\mathrm{mgI}_{2} \cdot 100 \mathrm{~g}^{-1}\right)\end{array}$ & $99.113 \pm 0.528^{\mathrm{d}}$ & $83.296 \pm 0.558^{b}$ & $56.266 \pm 1.092^{\mathrm{a}}$ & $90.775 \pm 0.842^{\mathrm{c}}$ \\
\hline $\begin{array}{c}\text { Saponification } \\
\text { value } \\
\left(\mathrm{mgKOH} \cdot \mathrm{g}^{-1}\right)\end{array}$ & $233.587 \pm 0.478^{\mathrm{d}}$ & $205.371 \pm 0.808^{\mathrm{a}}$ & $205.494 \pm 0.809^{c}$ & $209.198 \pm 0.791^{b}$ \\
\hline $\begin{array}{c}\text { Acid value } \\
\left(\mathrm{mgKOH} \cdot \mathrm{g}^{-1}\right)\end{array}$ & $18.827 \pm 0.309^{\mathrm{d}}$ & $13.701 \pm 0.235^{c}$ & $5.568 \pm 0.107^{\mathrm{a}}$ & $12.442 \pm 0.089^{\mathrm{b}}$ \\
\hline Free fatty acid (\%) & $9.463 \pm 0.155^{\mathrm{d}}$ & $6.915 \pm 0.09^{c}$ & $2,80 \pm 0.054^{\mathrm{a}}$ & $6.254 \pm 0.045^{\mathrm{b}}$ \\
\hline $\begin{array}{l}\text { Peroxyde value } \\
\quad\left(\mathrm{mEq} \cdot \mathrm{kg}^{-1}\right)\end{array}$ & $2.091 \pm 0.579^{\mathrm{a}}$ & $0.498 \pm 0.01^{\mathrm{b}}$ & $2.365 \pm 0.079^{\mathrm{a}}$ & $3.176 \pm 0.244^{\mathrm{a}}$ \\
\hline $\mathrm{k}_{232} \mathrm{~nm}$ & $1.492 \pm 0.177^{\mathrm{ab}}$ & $0.862 \pm 0.162^{c}$ & $1.284 \pm 0.029^{\mathrm{a}}$ & $1.737 \pm 0.292^{\mathrm{b}}$ \\
\hline $\mathbf{k}_{270} \mathrm{~nm}$ & $1.192 \pm 0.204^{\mathrm{ab}}$ & $0.883 \pm 0.281^{\mathrm{b}}$ & $1.571 \pm 0.048^{\mathrm{a}}$ & $1.479 \pm 0.471^{\mathrm{a}}$ \\
\hline$L^{*}$ & $85.42 \pm 0.391^{\mathrm{a}}$ & $85.15 \pm 0.13^{\mathrm{a}}$ & $89.30 \pm 0.02^{\mathrm{b}}$ & $96.16 \pm 0.01^{c}$ \\
\hline$a^{*}$ & $-7.74 \pm 0.367^{\mathrm{b}}$ & $-4.27 \pm 0.10^{\mathrm{d}}$ & $-6.96 \pm 0.05^{\mathrm{c}}$ & $-12.22 \pm 0.01^{\mathrm{a}}$ \\
\hline$b^{*}$ & $92.77 \pm 0.121^{\mathrm{a}}$ & $95.68 \pm 0.04^{\mathrm{c}}$ & $92.78 \pm 0.07^{\mathrm{a}}$ & $87.08 \pm 0.02^{\mathrm{b}}$ \\
\hline Y1 & $89.64 \pm 0.177^{\mathrm{c}}$ & $90.79 \pm 0.03^{\mathrm{d}}$ & $88.29 \pm 0.02^{\mathrm{b}}$ & $84.10 \pm 0.01^{\mathrm{a}}$ \\
\hline$c^{*}$ & $93.09 \pm 0.101^{\mathrm{a}}$ & $95.77 \pm 0.04^{c}$ & $93.05 \pm 0.06^{\mathrm{a}}$ & $87.93 \pm 0.01^{\mathrm{b}}$ \\
\hline $\mathrm{h}$ & $94.77 \pm 0.229^{c}$ & $92.55 \pm 0.03^{\mathrm{a}}$ & $94.29 \pm 0.03^{\mathrm{b}}$ & $97.99 \pm 0.01^{\mathrm{d}}$ \\
\hline
\end{tabular}

On the same line, averages with the same letter are not significantly different from the $5 \%$ threshold.

The extraction yield was higher with chloroform than with hexane or acetone. Indeed, these yields were $6.28 \% ; 23.05 \% ; 30.29 \%$ and $40.12 \%$ respectively with pressing, acetone, $n$-hexane and chloroform. Therefore, the lower polar solvents (n-hexane and chloroform) exhibited the highest oil extraction efficiencies. This difference noted between the hot extraction yields can be explained reasonably by the physicochemical properties of the solvents used [22] [28]. However, $\mathrm{n}$-hexane is mentioned in the literature as the most appropriate solvent for lipid extraction [29]. It is known that, n-hexane usually extracts only non-polar lipids and very little polar lipids. Acetone, a renewable organic solvent with a very low boiling point, would be miscible with all oils except palm [30]. Moreover, the results obtained are in agreement with those reported by Mani et al. [23] when optimizing the extraction of oil from Moringa oleifera seeds which were $33.47 \%$ and $30.33 \%$, respectively with hexane and acetone. On the other hand, Tir et al. [28] obtained sesame oil extraction yields of $43.75 \%$ and $37.23 \%$ respectively with hexane and acetone. The differences in extraction yields would be due to the operating parameters used such as temperature, particle size, extraction time 
and the ratio (solvent/particle size) [22] [23] [24] [25] [31]. In addition, we find that the extraction yield was $6.28 \%$ and $40.12 \%$ with pressing and chloroform, respectively. This notorious difference in performance indicates the large amount of residual oil still contained in the cakes after extraction by pressing.

With regard to density, a significant difference was noted on the extracted oils. Density is an important physical feature in the classification of oils. It depends on the fatty acid composition, the minor compounds and the temperature [32]. For the pressing oil, the density is 0.911 . Also, it is $0.882 \pm$ $0.016 ; 0.902 \pm 0.020$ and $0.945 \pm 0.013$ respectively for acetone, hexane and chloroform. Indeed, the density of the extracted oils varied with the evolution of the molar mass of the solvents used. These results also suggest a difference in the composition of the extracted oils. However, the results obtained are consistent with those of 0.880 and 0.943 reported on baobab seed oils by Buhari et al. [33] and Chindo et al. [18], respectively. These values are close to those of the oils of Moringa oleifera $(0.9032 \pm 0.03)$ and argan $(0.9158-0.9170)$ widely used in the cosmetic and pharmaceutical fields [34] [35].

The refractive index for assessing the purity of the oils is between 1.457 and 1.465. The analysis of the variance indicates that there is a significant difference at the $5 \%$ threshold for the measured refractive indexes. The refractive index is also affected by the polarity of the extraction solvents. In fact, the oils extracted with the two most polar solvents (chloroform and acetone) had the lowest refractive index. As a result, these two oils would have more long chain fatty acids than other oils. According to Shahidi [32], the lipid refractive index varies according to the molecular weight, the chain length of the fatty acids, the degree of unsaturation and the degree of conjugation. The determined values are in agreement with those obtained by Chadare et al. [36] and Nkafamiya et al. [17]. These refractive index obtained are comparable with those of Nigella spseed oil (1.46 - 1.47), Jatropha curcus (1.468 - 1.469), olive (Olea europaea L.) (1.468) and argan (Argania spinosa L.) (1.468 - 1.471) [37] [38] [39] [40]. In addition, the refractive index is an important property that can detect adulteration of vegetable oils. Based on the iodine and refractive indices, we can say that baobab oil is non-drying.

The specific absorption at $232 \mathrm{~nm}$ for oils extracted by pressing and solvents (n-hexane, acetone and chloroform) are below the limit values set by the International Oleic Council (IOC) [41] and the Codex Alimentarius [42] for oils from virgin olives which are respectively 2.60 and 3.5. Indeed, it allows, at 232 $\mathrm{nm}$, to evaluate the presence of the primary products of oxidation of fatty acids (linoleic hydroperoxides, oxidized fatty acids) while at $270 \mathrm{~nm}$ are detected the secondary oxidation products (alcohols, ketones...) [43]. The specific extinction at $232 \mathrm{~nm}$ of the oil extracted with hexane is consistent with the value of 1.73 reported by Gharby et al. [44] for sesame oil. Also, the extinction coefficient at $232 \mathrm{~nm}$ of oil extracted with acetone $(0.862 \pm 0.162)$ is lower than those extracted with chloroform (1.284 \pm 0.029$)$, $n$-hexane $(1.737 \pm 0.292)$ and 
pressing $(1.492 \pm 0.177)$. These results indicate that the extinction coefficient $k_{232}$ increases with the polarity of the solvents. In addition, the primary oxidation products are lower for the oil extracted with acetone than with those extracted with chloroform, $\mathrm{n}$-hexane or pressing. The oil obtained with acetone is less oxidized than those obtained with chloroform, n-hexane and pressing. This trend was also reflected by the lower peroxide value with the oil extracted with acetone. Ultimately, baobab oil extracted with acetone would be more resistant to oxidation compared to other oils. On the other hand, the specific extinction at $270 \mathrm{~nm}$ between 0.883 and 1.571 remains above the limit value allowed for virgin olive oils [42]. The results obtained show that the oil extracted with the most polar solvent (acetone) had the lowest extinction coefficient $\mathrm{k}_{270}$. Therefore, the secondary oxidation products would be less important in the oil extracted with acetone than in the other oils. Also, the extinction coefficients $k_{270} \mathrm{~nm}$ measured have significantly varied with the polarity of the solvents used and the boiling temperature of the extraction solvents. The results recorded also suggest that these secondary oxidation products would be lower in the pressed oil than in those derived from $\mathrm{n}$-hexane or chloroform. However, the specific extinction at $270 \mathrm{~nm}$ of the oil extracted with chloroform remains similar to that of $1.54 \pm$ 0.07 reported by Azhari et al. [45] for breast milk oil (Cucumis melo vartibis).

The color parameters $\left(\mathrm{L}^{\star}, \mathrm{a}^{\star}, \mathrm{b}^{\star}, \mathrm{Y} 1, \mathrm{c}^{\star}\right.$ and $\left.\mathrm{h}\right)$ of the extracted oils are given in Table 1 . The lowest and highest luminosity $\mathrm{L}^{*}$ were respectively noted on the acetone $(85.15 \pm 0.13)$ and hexane $(96.16 \pm 0.01)$. This parameter $L^{*}$ characterizing the ability of a sample to reflect light more or less shows that the oil extracted with $n$-hexane is brighter than those extracted with pressing, acetone and chloroform. However, the brightness $L^{*}$ of oils extracted by pressing and acetone are similar. Similarly, the color parameter $\mathrm{a}^{*}$ indicating the color hue between green and red is $-12.22 \pm 0.01 ;-7.74 \pm 0.367 ;-6.96 \pm 0.05$ and $-4.27 \pm 0.10$ respectively for the oils obtained with $\mathrm{n}$-hexane, pressing, chloroform and acetone. Indeed, the oil extracted with hexane draws more towards the red coloring than those extracted with chloroform, acetone and pressing. Also, the parameter $\mathrm{b}^{*}$ corresponding to the color shade between blue and yellow varies according to the different oils extracted. The highest value of $\mathrm{b}^{*}$ was obtained with acetone which is $95.68 \pm 0.04$. This value indicates that the oil extracted with acetone is more yellow than those obtained with chloroform, hexane and pressing.

This value indicates that the oil extracted with acetone is more yellow than those obtained with chloroform, $n$-hexane and pressing. The $b^{*}$ parameter of the oil obtained by pressing is also similar to that obtained with chloroform. The yellowness index Y1 of the oil extracted with acetone $(90.79 \pm 0.03)$ confirms the accentuated coloration of the yolk. On the other hand, Y1 yellowing index values of the oil extracted by pressing and acetone are very close. As a result, the latter two would contain a larger amount of carotenoids [46] [47]. The difference in color observed between the oils obtained at high temperature could be attributed 
to the polarity of the solvents. Thus, the physicochemical characteristics of the oils extracted differ according to the properties of the solvents used. In addition, Al-farga et al. [48] reported with the oil of alhydwan seeds (Boerhawia elegana Choisy) the values $65.44\left(\mathrm{~L}^{*}\right), 1.11\left(\mathrm{a}^{*}\right)$ and $28.33\left(\mathrm{~b}^{*}\right)$. In contrast, Shao et al. [47] had obtained $39.26\left(\mathrm{~L}^{\star}\right), 30.56\left(\mathrm{a}^{\star}\right)$ and $50.40\left(\mathrm{~b}^{\star}\right)$ values with tomato seed oil. Data processing by variance analysis shows that there are significant differences at the $5 \%$ level.

\subsection{Chemical Properties}

Table 2 contains the chemical properties of cold-pressed baobab oils and organic solvents. The acid value reports the degradation state of oil by evaluating the amount of free fatty acids formed during extraction or storage. The acid values were between 5.568 and $18.827 \mathrm{mgKOH} \cdot \mathrm{g}^{-1}$ respectively with chloroform and pressing method. The acid value noted varies significantly with the polarity of the solvents. In fact, the oils extracted with organic solvents revealed the weakest acid level. Consequently, the hydrolysis of the ester bonds of the triglycerides is greater in the oil resulting from pressing than in those resulting from solvents. At the same time, the increase in the acid value causes a change in the content of glycerol and of free fatty acids in the oil [49]. From these results, we can say that the quality of hot-extracted baobab oils is less altered than that of cold pressure. The latter is therefore less sensitive to rancidity during extraction. In addition, these values are very high compared to those reported by Nkafamiya et al. [17] $\left(0.33 \mathrm{mgKOH} \cdot \mathrm{g}^{-1}\right)$ and Birnin-Yauri and Garba [19] (3.14 $\left.\mathrm{mgKOH} \cdot \mathrm{g}^{-1}\right)$. However, the acid value of the oil extracted with chloroform is close to those obtained by Ajayi [50] (5.19 $\left.\mathrm{mgKOH} \cdot \mathrm{g}^{-1}\right)$ and Oyeleke et al. [51] (6.52 $\left.\mathrm{mgKOH} \cdot \mathrm{g}^{-1}\right)$. The acid values obtained are also higher than the limit value recommended by the European Pharmacopoeia [52]. These recorded results could be reasonably explained by the pretreatment applied to baobab seeds and/or the presence of a highly active lipase which would lead to rapid acidification of baobab oil during extractions [53]. Also, these important values can be attributed to the heating temperature of the screw head or boiling solvents. According to Tchiégang et al. [54], the temperature would cause the hydrolysis of one or two of the ester bonds of triglycerides favoring the formation of free fatty acids. In contrast, Brevedan et al. [55] reported a higher acid value for sunflower with $\mathrm{n}$-hexane than with pressing.

Table 2. The polyphenols content and the antioxidant activity of the oils extracted by pressing and organic solvents.

\begin{tabular}{ccccc}
\hline Parameters & Pressure & Acetone & Chloroform & n-Hexane \\
\hline $\begin{array}{c}\text { Polyphenols } \\
(\text { mgEAG/g) }\end{array}$ & $0.047 \pm 0.0024^{\mathrm{b}}$ & $0.026 \pm 0.003^{\mathrm{a}}$ & $0.025 \pm 0.002^{\mathrm{a}}$ & $0.028 \pm 0.004^{\mathrm{a}}$ \\
DPPH (\%) & $31.71 \pm 0.610^{\mathrm{d}}$ & $26.38 \pm 0.600^{\mathrm{c}}$ & $9.23 \pm 0.670^{\mathrm{a}}$ & $1527 \pm 0.150^{\mathrm{b}}$ \\
\hline
\end{tabular}

On the same line, averages with the same letter are not significantly different from the 5\%. 
The iodine value is used to determine the degree of unsaturation of a vegetable oil and to assess stability during storage [56]. The registered iodine value varies significantly with the extraction process. Indeed, this index was between 56.266 and $99.113 \mathrm{mgI}_{2} \cdot 100 \mathrm{~g}^{-1}$ and seems to be affected by the polarity of the extraction solvents. Also, the oil extracted with chloroform showed the lowest iodine value $\left(56.266 \pm 1.092 \mathrm{mgI}_{2} \cdot 100 \mathrm{~g}^{-1}\right)$. Therefore, this high quality oil would be more resistant to oxidation and have a longer shelf life. This iodine valueindicates the low percentage of acidity $(2.80 \% \pm 0.054 \%)$ of this oil. In other words, the oil extracted with chloroform would contain the lowest amounts of oleic and linoleic acids. The iodine values below $100 \mathrm{mgI}_{2} \cdot 100 \mathrm{~g}^{-1}$ make it possible to classify baobab oil as non-drying oils [57]. The oils extracted by pressing, n-hexane and acetone showed the highest iodine values. These high iodine levels suggest the high unsaturated fatty acid content of these oils. Ultimately, baobab oil is comparable to olive oil $\left(75-94 \mathrm{mgI}_{2} \cdot 100 \mathrm{~g}^{-1}\right)$ widely used by the cosmetics and pharmaceutical industries [38]. The results obtained are in agreement with those indicated by Nkafamiya et al. [17] and Danbature et al. [21]. The iodine value seems to decrease with the polarity of the solvents.

The peroxide value permit to understand the degree of oxidation of the unsaturated fatty acids. Indeed, the oxidation of the oils leads to the formation of hydroperoxides, primary products of oxidation. Thus, the peroxide value corresponding to the hydroproxide content represents a very useful and very sensitive criterion for assessing the first stages of the oxidative deterioration of a fatty substance and an oil during production and storage [58] [59]. This standard method is included in the specifications for "fatty substances" with a threshold value of 10 meq $\mathrm{O}_{2}$ per $\mathrm{kg}$ of material for a refined oil [58] [60]. In other words, all the peroxide values of the baobab oils obtained are lower than this limit value of $10 \mathrm{mEq} \cdot \mathrm{kg}^{-1}$ fixed by the Codex Alimentarius [52]. The quality of the oil extracted with acetone is better than other oils. Indeed, the combination of the peroxide value with the extinction coefficients $\left(k_{232}\right.$ and $\left.k_{270}\right)$ shows that the oxidative stability of the oil extracted with acetone is relatively better, which could be explained by the presence of natural antioxidants such as tocopherols, sterols, carotenoids and phenolic compounds [30] [44] [61]. Moreover, these results suggest that the oil extracted with acetone would be less oxidized and less sensitive to deterioration than those extracted by pressing or with chloroform and $n$-hexane. Also, the peroxide value of the pressing oil could be explained by the temperature reached during the extraction. The results obtained are close to those reported by Adebayo et al. [62] with kariya seed oil (Hildergadia berteri). However, the peroxide values obtained are lower than those of palm oils (16.08 $\left.\mathrm{mEq} \cdot \mathrm{kg}^{-1}\right)$ and sorrel (Hibicus sabdariffa) $\left(5.00 \pm 0.01 \mathrm{mEq} \cdot \mathrm{kg}^{-1}\right)$ respectively reported by Birnin-Yauri and Garba [19] and Betiku and Adepoju [63]. The variance analysis indicates that there are significant differences at the $5 \%$ threshold of the peroxide values. The oxidative deterioration of oils during extraction and storage operations has been extensively studied and the titration method has been the most widely used [17] [19] [27] [40] [43] [44] [46] [55]. 
However, this method is complex and long [59] [64]. Also, Sahhidi and Zhong [59] pointed out the possible interference in the determination of light, oxygen and iodine uptake by unsaturated fatty acids. In addition, the peroxide value is a measure that can be used only for samples whose autoxidation is not too advanced [65].

The saponification values measured are 233.587; 205.494; 205.371 and $209.198 \mathrm{mgKOH} \cdot \mathrm{g}^{-1}$ respectively for oils extracted with pressing, chloroform, acetone and $\mathrm{n}$-hexane. This significant difference noted between the extracted oils can be attributed to the extraction time and/or the physicochemical properties of the solvents. The baobab seed-oil obtained by pressure reveals the highest saponification value. Therefore, this baling oil would contain more short-chain fatty acids for stability during storage. The baobab oils extracted with organic solvents showed the lowest saponification values. These indicate a predominance of long chain fatty acids in these oils [66]. Very important for the food and cosmetics industries, oils with high saponification values would be less sensitive to deterioration [67]. The results also indicate that the saponification values are higher than those of Persea americana oil (35.76 mgKOH/g) [27], argan oil (190.88 $\mathrm{mgKOH} / \mathrm{g})$ [68] and olive oil $(97.94 \mathrm{mgKOH} / \mathrm{g})$ [46]. Thus, the high saponification value of baobab seed oil indicates the high potential for its use in the manufacture of soaps.

\subsection{Antioxidant Potential of Extracted Oils}

In order to estimate the quality of the oils extracted, the polyphenol content and the radical scavenging activitywere measured. The results obtained are listed in Table 2. These results indicate that the oil extracted by cold pressing was the richest sample of polyphenols with $0.047 \pm 0.0024 \mathrm{mgEAG} / \mathrm{g}$ of oil followed by the oils extracted with the hexane $(0.028 \pm 0.004 \mathrm{mgEAG} / \mathrm{g}$ oil $)$, acetone $(0.026 \pm$ $0.003 \mathrm{mgEAG} / \mathrm{g}$ oil) and chloroform $(0.025 \pm 0.002 \mathrm{mgEAG} / \mathrm{g}$ oil $)$. In fact, according to Salih and Yahia [69], baobab seeds (Adansonia digitata L.) contain a polyphenol content of $6.689 \pm 0.086 \mathrm{mgEAG} / \mathrm{g}$ of seed. With the latter, we can also say that the amount of polyphenols found in oils remains very low. The oil resulting from pressing contains higher polyphenol content. Thus, the application of this oil on the dermatological level would be more beneficial. In addition, this difference in terms of phenolic compounds between the pressing oil and those obtained with solvents results from the extraction method [70], the extraction time achieved and/or the physicochemical properties of the solvents used. Indeed, natural antioxidants (tocopherols, carotenoids, etc.) influence the lipid oxidation [71]. Therefore, oils extracted by pressing and with acetone will be less susceptible to oxidation during storage. However, the polyphenol contents of the various oils extracted are lower than that of Persea americana oil ( $8.27 \pm$ $0.06 \mathrm{mgEAG} / \mathrm{g}$ of oil) reported by Adaramola et al. [27]. The treatment of the data by analysis of the variances shows that there is a significant difference at the threshold of $5 \%$. The antioxidant activity of the extracted oils varied according to the extraction process. 
The results obtained reveal that oils have variableradical scavenging activities. In other words, our results reveal that the pressing oil has the highest polyphenol content and radical scavenging activity. This antioxidant activity of the pressing oil could be explained by its high content of phenolic compounds. Indeed, some studies have reported a positive correlation between antioxidant activity and phenol content [72] [73]. For hot extraction, oil extracted with acetone was rated as the most active with antioxidant activity estimated at $26.38 \% \pm 0.60 \%$. This value remains comparable to that of olive oil $(25.38 \% \pm 0.64 \%)$ reported by Merouane et al. [74].

\subsection{Statisticalanalysis}

\subsubsection{Correlations between Physicochemical Characteristics and Antioxidant Potential of Baobab Oils}

The correlation analysis between the physicochemical characteristics of the extracted oils and the antioxidant potential shows a very strong negative correlation of the extraction yield with the radical scavenging activity, the polyphenol content, the acid value, the iodine value and saponification value (Table 3). This table shows that the polyphenol content was negatively correlated with the extraction yield, and positively correlated with theradical scavenging activity. This positive correlation between polyphenol content and radical scavenging activityis consistent with the results obtained through several studies [72] [73]. On the other hand, the acid and iodine values are very negatively correlated with the extraction yield, and inversely correlated with the anti-radical activity, the polyphenol content and the refractive index. Similarly, saponification value was positively correlated with yield, and negatively correlated with polyphenol content and acid value. Also, we also find that the peroxide value was positively correlated with the specific extinction coefficients $\left(k_{232}\right.$ and $\left.k_{270}\right)$, the luminescence $L^{*}$ and the chromatic tone $h$, and inversely correlated with the parameters $\mathrm{a}^{*}$ and $\mathrm{b}^{*}$. The very strong correlations between the extinction coefficients and the peroxide value attest to the spectrophotometric approach for evaluating the oxidation state of a fatty substance. Our results are also in agreement with those reported by Guzmán et al. [75]. According to them, there was no correlation between the variables peroxide and acid values. On the other hand, the color parameters $\left(\mathrm{a}^{*}, \mathrm{~b}^{*}\right.$ and $\left.\mathrm{Y} 1\right)$ were negatively correlated with the peroxide value, the specific extinction $k_{232}$ and the luminescence $L^{*}$. The $h$ color tone has a positive correlation with the peroxide value, the specific extinction $\mathrm{k}_{232}$ and the $\mathrm{L}^{*}$ luminescence, and a negative correlation with the parameters $\mathrm{a}^{*}, \mathrm{~b}^{*}$ and $\mathrm{Y} 1$.

\subsubsection{Principal Component Analysis}

Principal component analysis (PCA) was carried out to evaluate the effect of pressing and/or solvents (acetone, chloroform and n-hexane) on the physicochemical characteristics and antioxidant potential of the extracted oils (Figure 1 and Figure 2). The first two dimensions (Dim 1 and Dim 2) express 
Table 3. Pearson correlation coefficients between physicochemical characteristics and antioxidant potential of baobab oils (Adansonia digitata L.).

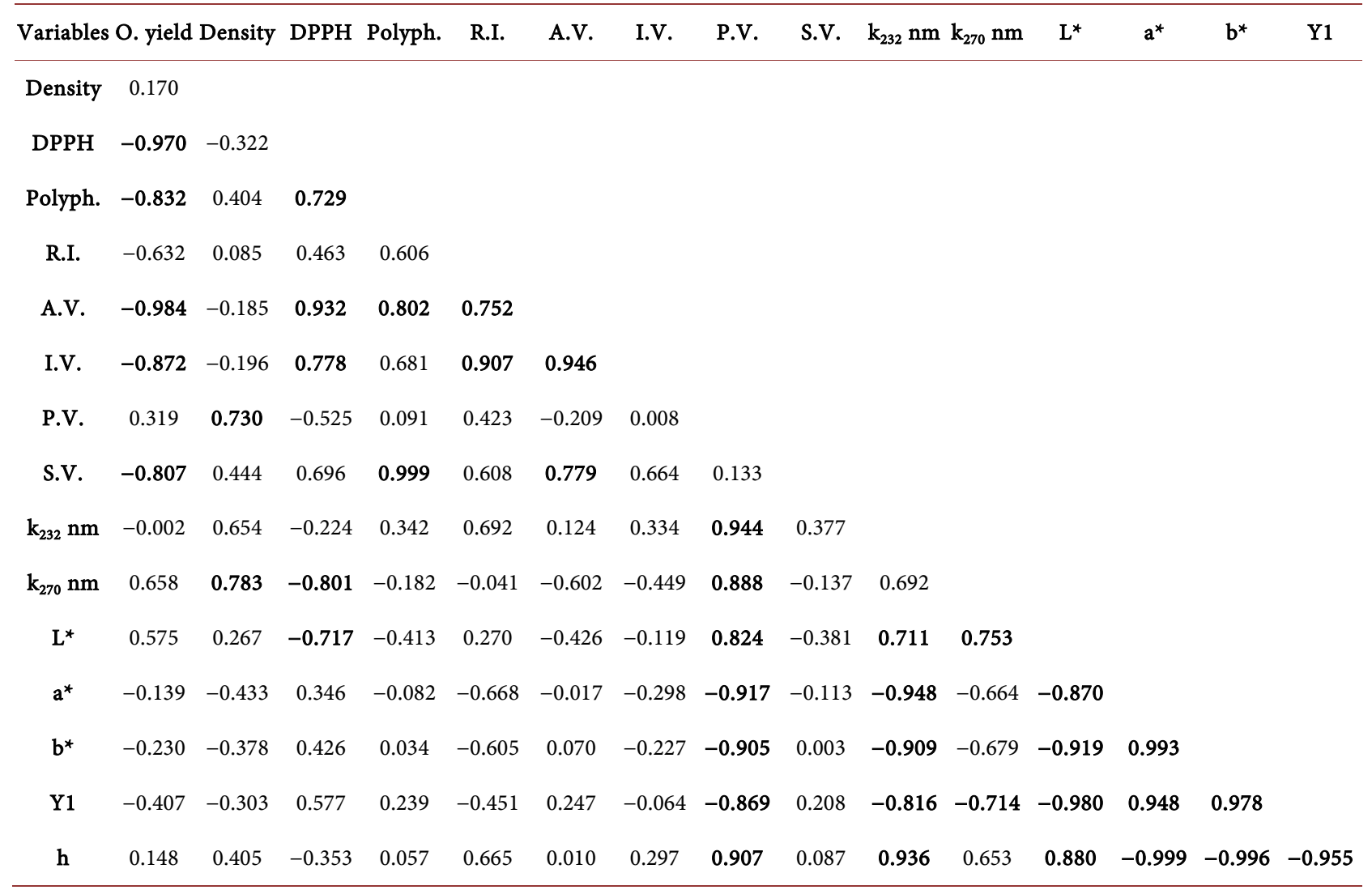

O. yield: oil yield; R.I.: refractive index; S.V.: saponification value; P.V.: peroxide value; A.V.: acid value; I.V.: iodine value; Polyph.: polyphenols.

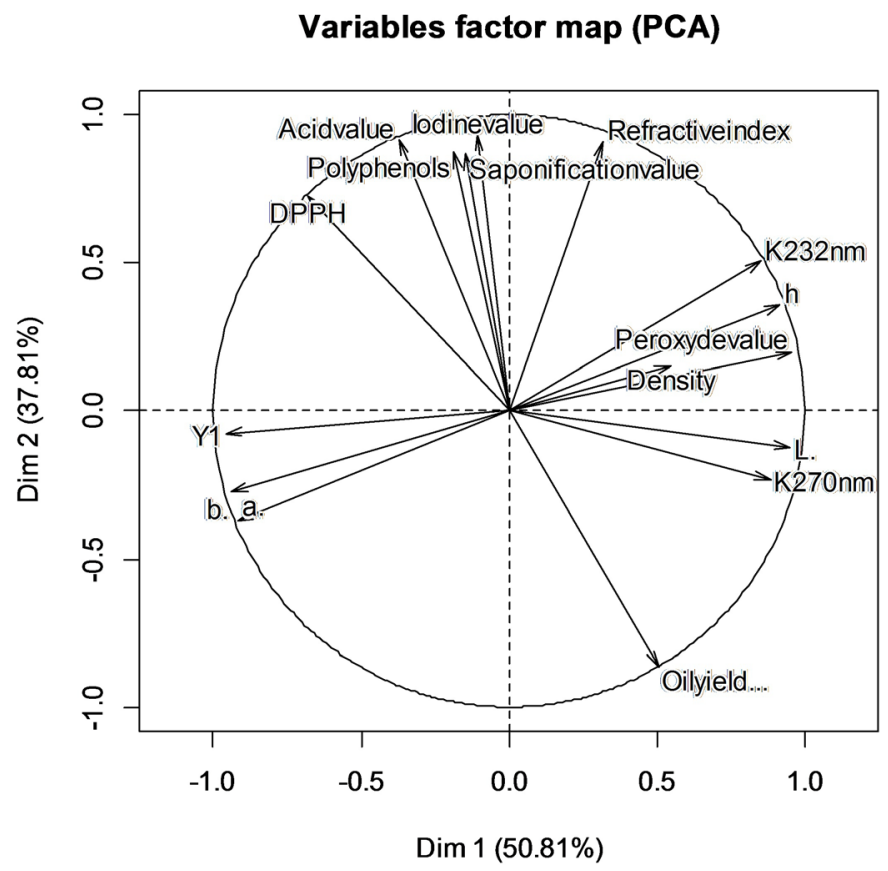

Figure 1. Correlation between physicochemical properties and the antioxidant potential of baobab oils and the first two dimensions of PCA. 


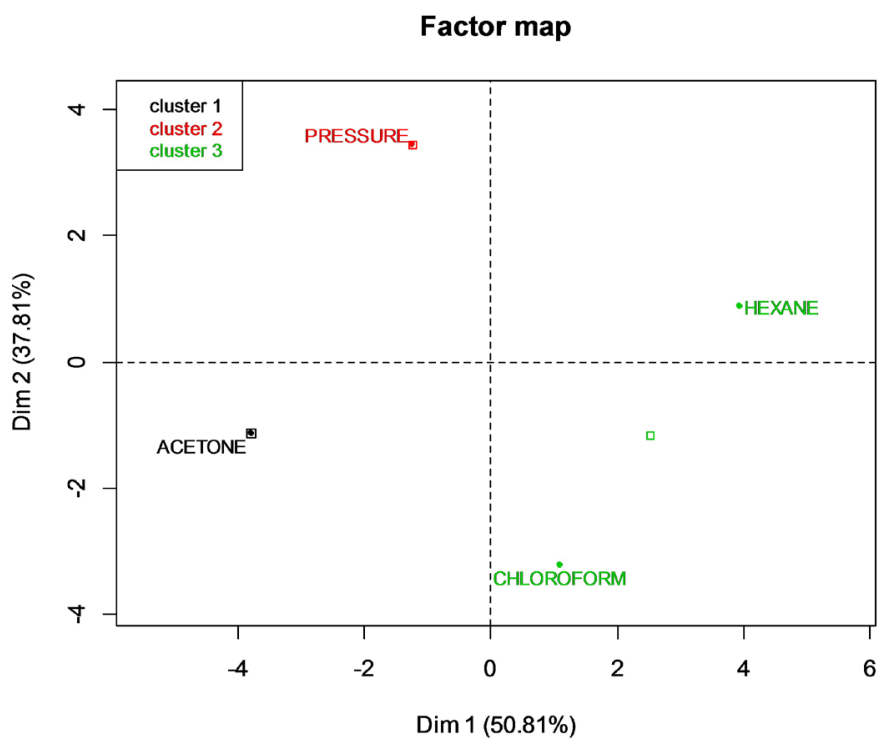

Figure 2. Projection of the different extraction methods according to the physicochemical properties of the extracted oils in the factorial plane of the PCA.

$88.62 \%$ of the total variance. Indeed, the first dimension (Dim 1) contributes to $50.81 \%$ and the second dimension (Dim 2) to $37.81 \%$. The density variables, peroxide value, specific extinction coefficients $\left(k_{232}\right.$ and $\left.k_{270}\right)$, luminescence $L^{*}$ and chromatic tone $h$ are positively correlated with the first axis, while variables $\mathrm{a}^{*}$ (color shade between green and red), $\mathrm{b}^{*}$ (shade of color between blue and yellow) and yellowness index Y1 are negative. The parameters for evaluating the oxidation state of the extracted oils are well aligned with this first dimension (Dim 1), which could be considered as an axis of quality. Moreover, the polyphenol variables, radical scavenging activity, refractive index, acid value and iodine value are positively correlated to the second dimension (Dim 2). On the other hand, the yield variable is negatively correlated with this dimension (Dim 2). Furthermore, the parameters representing the antioxidant potential, the state of conservation and the identification of the oils obtained are well aligned with this second dimension. The dimensional axes (Dim 1 and Dim 2) delimit the types of solvents and extraction used. The position on the axis Dim 1 differentiates the oil with the peroxide value, density, specific extinction coefficients ( $\mathrm{k}_{232}$ and $\mathrm{k}_{270} \mathrm{~nm}$ ), luminescence $\mathrm{L}^{*}$ and $\mathrm{h}$ ( $\mathrm{n}$-hexane) color tone, to the other oils characterized by the color parameters $\left(\mathrm{a}^{*}\right.$ and $\left.\mathrm{b}^{*}\right)$ and yellowness index Y1 (acetone and chloroform). However, the position on the axis Dim 2 opposes the oils with a polyphenol content, an free radical scavenging activity, a refractive index, a saponification value and a high iodine value (oil extracted by pressing), oils (extracted with chloroform and acetone) in low yield. Thus, based on the physicochemical properties of the oils, it is clear that the oil extracted by pressing best retains its quality. Nevertheless, the solvents (acetone, chloroform and $n$-hexane) make it possible to obtain oils with a lower radical scavenging activity and Y1 yellowing index. The oil extraction methods have been grouped 
into three classes. The first class is the oil extracted with acetone. The latter is characterized by a yellowness index and color parameters $\left(\mathrm{a}^{\star}\right.$ and $\left.\mathrm{b}^{\star}\right)$. Class 2 consists of oil extracted by cold pressing. Finally, class 3 consists of the less polar solvents (chloroform and n-hexane).

\section{Conclusion}

In this study, the impact of pressing and solvents on physicochemical characteristics, polyphenol content and radical scavenging activity of baobab oils extracted was determined. The results obtained reveal that the oil extracted by pressing retains at best its physicochemical properties and contains a very high content of phenolic compounds and radical scavenging activity. Also, this oil produced by pressing exhibits a more intense yellow coloration than that obtained from the solvents. However, chloroform provides the best extraction yield. The extraction with $\mathrm{n}$-hexane makes it possible to obtain oils whose physicochemical characteristics are less attenuated. With organic solvents, the oil extracted with acetone, the most polar solvent, exhibits an acceptable radical scavenging activity. Taken together, these results provide fundamental element for decision making regarding the method of extraction to use for specific addressed use of baobab oil. These results suggest the mixed use of acetone and hexane for better conservation of the chemical and bioactive characteristics of baobab oil. Therefore, further studies will be needed to determine the optimal conditions for extracting oil comparable to cold pressed oil and for identifying bioactive compounds.

\section{Conflicts of Interest}

The authors declare no conflicts of interest regarding the publication of this paper.

\section{References}

[1] Korbo, A., Kjær, E.D., Sanou, H., Ræbild, A., Jensen, J.S. and Hansen, J.K. (2013) Breeding for High Production of Leaves of Baobab (Adansonia digitata L) in an Irrigated Hedge System. Tree Genetics and Genomes, 9, 779-793. https://doi.org/10.1007/s11295-013-0595-y

[2] Assogbadjo, A.E. and Loo, J. (2011) Adansonia digitata; African Baobab. Conservation and Sustainable Use of Genetic Resources of Priority Food Tree Species in Sub-Saharan Africa. Bioversity International, Rome.

[3] Diop, A.G., Sakho, M., Dornier, M., Cisse, M. and Reynes, M. (2006) Le Baobab Africain (Adansonia digitata L.): Principales Caractéristiques et Utilisations. Fruits, 61, 55-69. https://doi.org/10.1051/fruits:2006005

[4] Gebauer, J., El-Siddig, K. and Ebert, G. (2002) Baobab (Adansonia digitata L.): A Review on a Multipurpose Tree with Promising Future in the Sudan. Gartenbauwissenschaft, 67, 155-160.

[5] Kerharo, J. and Adam, J.G. (1974) La Pharmacopée Sénégalaise Traditionnelle: Plantes Médicinales et Toxiques. Vigot Frères, Paris.

[6] Sidibe, M. and Williams, J.T. (2002) Baobab, Adansonia digitata L. Fruits for the 
Future 4. International Center for Underutilized Crops (ICUC): University of Southampton, Southampton.

[7] Buchmann, C., Prehsler, S., Hartl, A. and Vogl, C.R. (2010) The Importance of Baobab (Adansonia digitata L.) in Rural West African Subsistence-Suggestion of a Cautionary Approach to International Market Export of Baobab Fruits. Ecology of Food and Nutrition, 49, 145-172. https://doi.org/10.1080/03670241003766014

[8] Wickens, G.E. and Lowe, P. (2008) The Baobabs: Pachycauls of Africa, Madagascar and Australia. Springer, Berlin. https://doi.org/10.1007/978-1-4020-6431-9

[9] Parkouda, C., Sanou, H., Tougiani, A., Korbo, A., Nielsen, D.S., Tano-Debrah, K., Ræbild, A., Diawara, B. and Jensen, J.S. (2012) Variability of Baobab (Adansonia digitata L.) Fruits' Physical Characteristics and Nutrient Content in the West African Sahel. Agroforestry Systems, 85, 455-463.

https://doi.org/10.1007/s10457-011-9406-3

[10] Gebauer, J. and Luedeling, E. (2013) A Note on Baobab (Adansonia digitata L.) in Kordofan, Sudan. Genetic Resources and Crops Evolution, 60, 1587-1596. https://doi.org/10.1007/s10722-013-9964-5

[11] Osman, M.A. (2004) Chemical and Nutrient Analysis of Baobab (Adansonia digitata) Fruit and Seed Protein Solubility. Plant Foods for Human Nutrition Formerly Qualitas Plantarum, 59, 29-33. https://doi.org/10.1007/s11130-004-0034-1

[12] Zahra'u, B., Mohammed, A.S., Ghazali, H.M. and Karim, R (2014) Baobab Tree (Adansonia digitata L) Parts: Nutrition, Applications in Food and Uses in Ethno-Medicine-A Review. Annalsof Nutritional Disordersand Therapy, 1, 1011.

[13] Vermaak, I., Kamatou, G.P.P., Komane-Mofokeng, B., Viljoen, A.M. and Beckett, K. (2011) African Seed Oils of Commercial Importance-Cosmetic Applications. South African Journal of Botany, 77, 920-933. https://doi.org/10.1016/j.sajb.2011.07.003

[14] Cissé, I. (2012) Caractérisation des Propriétés Biochimiques et Nutritionnelles de la Pulpe de Baobab des Espèces Endémiques de Madagascar et d'Afrique Continentale en vue de Leur Valorisation. Thèse, Montpellier Supagro, Montpellier.

[15] Kamatou, G.P.P., Vermaak, I. and Viljoen, A.M. (2011) An Updated Review of Adansonia digitata: A Commercially Important African Tree. South African Journal of Botany, 77, 908-919. https://doi.org/10.1016/j.sajb.2011.08.010

[16] Namratha, V. and Sahithi, P. (2015) Baobab: A Review about "The Tree of Life". International Journal of Advanced Herbal Scienceand Technology, 1, 20-26.

[17] Nkafamiya, I.I., Osemeahon, S.A., Dahiru, D. and Umaru, H.A. (2007) Studies on the Chemical Composition and Physicochemical Properties of the Seeds of Baobab (Adasonia digitata). African Journal of Biotechnology, 6, 756-759.

[18] Chindo, I.Y., Gushit, J.S., Olotu, P.N., Mugana, J. and Takbal, D.N. (2010) Comparism of the Quality Parameters of the Seed and Condiment Oil of Adansonia digitata. Journal of American Science, 6, 990-994.

[19] Birnin-Yauri, U.A. and Garba, S. (2011) Comparative Studies on Some Physicochemical Properties of Baobab, Vegetable, Peanut and Palm Oils. Nigerian Journalof Basic and Applied Science, 19, 64-67.

[20] Abubakar, S., Etim, V., Bwai, D. and Afolayan, M. (2015) Nutraceutical Evaluation of Baobab (Adansonia digitata L.) Seeds and Physicochemical Properties of Its Oil. Annals of Biological Sciences, 3, 13-19.

[21] Danbature, W.L., Yirankinyuki, F.F., Magaji, B. and Mela, Y. (2015) Effect of Seed Strorage on the Physic-Chemical Properties of Its Oil (Adansonia digitata). Interna- 
tional Interdisciplinary Journal of Scientific Research, 2, 1-7.

[22] Sayyar, S., Abidin, Z.Z., Yunus, R. and Muhammad, A. (2009) Extraction of Oil from Jatropha Seeds-Optimization and Kinetics. American Journal of Applied Sciences, 6, 1390-1395. https://doi.org/10.3844/ajassp.2009.1390.1395

[23] Mani, S., Jaya, S. and Vadivambal, R. (2007) Optimization of Solvent Extraction of Moringa (Moringa Oleifera) Seed Kernel Oil Using Response Surface Methodology. Food and Bioproducts Processing, 85, 328-335. https://doi.org/10.1205/fbp07075

[24] Liauw, M.Y., Natan, F.A., Widiyanti, P., Ikasari, D., Indraswati, N. and Soetaredjo, F.E. (2008) Extraction of Neem Oil (Azadirachta indica A. Juss) Using n-Hexane and Ethanol: Studies of Oil Quality Kinetic and Thermodynamic. Journal of Engineering and Applied Sciences, 3, 49-54.

[25] Saxena, D.K., Sharma, S.K. and Sambi, S.S. (2011) Kinetics and Thermodynamics of Cottonseed Oil Extraction. Grasas y Aceites, 62, 198-205. https://doi.org/10.3989/gya.090210

[26] Georgé, S., Brat, P., Alter, P. and Amiot, M.J. (2005) Rapid Determination of Polyphenols and Vitamin C in Plant-Derived Products. Journal of Agricultural and Food Chemistry, 53, 1370-1373. https://doi.org/10.1021/jf048396b

[27] Adaramola, B., Onigbinde, A. and Shokunbi, O. (2016) Physiochemical Properties and Antioxidant Potential of Persea americana Seed Oil. Chemistry International, 2, 168-175.

[28] Tir, R., Dutta, P.C. and Badjah-Hadj-Ahmed, A.Y. (2012) Effect of the Extraction Solvent Polarity on the Sesame Seeds Oil Composition. European Journal of Lipid Science and Technology, 114, 1427-1438. https://doi.org/10.1002/ejlt.201200129

[29] Russin, T.A., Boye, J.I., Arcand, Y. and Rajamohamed, S.H. (2011) Alternative Techniques for Defatting Soy: A Practical Review. Food and Bioprocess Technology, 4, 200-223. https://doi.org/10.1007/s11947-010-0367-8

[30] Bhatnagar, A.S. and Gopala Krishna, A.G. (2013) Effect of Extraction Solvent on Oil and Bioactives Composition of Commercial Indian Niger (Guizotia abyssinica (L.f.) Cass.) Seed. Journal of the American Oil Chemists' Society, 90, 1203-1212. https://doi.org/10.1007/s11746-013-2263-7

[31] Kostić, M.D., Joković, N.M., Stamenković, O.S., Rajković, K.M., Milić, P.S. and Veljković, V.B. (2013) Optimization of Hempseed Oil Extraction by n-Hexane. Industrial Crops and Products, 48, 133-143. https://doi.org/10.1016/j.indcrop.2013.04.028

[32] Shahidi, F. (2005) Quality Assurance of Fats and Oils. In: Shahidi, F., Ed., Bailey's Industrial Oil and Fat Products, John Wiley\& Sons, Inc., Hoboken, 565-576.

[33] Buhari, M., Danbature, W.L., Muzakir, M.M. and Abubakar, B.A. (2014) Production of Biodiesel from Baobab Seed Oil. Greener Journal of Agricultural Sciences, 4, 22-26. https://doi.org/10.15580/GJAS.2014.2.1219131042

[34] Taribak, C., Casas, L., Mantell, C., Elfadli, Z., Metni, R.E. and Martínez de la Ossa, E.J. (2013) Quality of Cosmetic Argan Oil Extracted by Supercritical Fluid Extraction from Argania spinosa L. Journal of Chemistry, 2013, Article ID: 408194. https://doi.org/10.1155/2013/408194

[35] Anwar, F., Hussain, A.I., Iqbal, S. and Bhanger, M.I. (2007) Enhancement of the Oxidative Stability of Some Vegetable Oils by Blending with Moringa oleifera Oil. Food Chemistry, 103, 1181-1191. https://doi.org/10.1016/j.foodchem.2006.10.023

[36] Chadare, F.J., Linnemann, A.R., Hounhouigan, J.D., Nout, M.J.R. and Van Boekel, M.A.J.S. (2008) Baobab Food Products: A Review on Their Composition and Nutri- 
tional Value. Critical Reviews in Food Science and Nutrition, 49, 254-274. https://doi.org/10.1080/10408390701856330

[37] Cheikh-Rouhou, S., Besbes, S., Hentati, B., Blecker, C., Deroanne, C. and Attia, H. (2007) Nigella sativa L.: Chemical Composition and Physicochemical Characteristics of Lipid Fraction. Food Chemistry, 101, 673-681. https://doi.org/10.1016/j.foodchem.2006.02.022

[38] Djenotin, T.S., Dangou, J., Wotto, V.D., Sohounlhoue, D.K.C., Lozano, P. and Pioch, D. (2006) Composition en acides gras, sterols et tocopherols de l'huile vegetale non conventionnelle extraite des graines de Jatropha curcas (Euphorbiaceae) du Benin. Journal de la Société Ouest Africainede Chimie, 22, 59-67.

[39] Salimon, J. and Abdullah, R. (2008) Physicochemical Properties of Malaysian Jatropha curcas Seed Oil. Sains Malaysiana, 37, 379-382.

[40] Adlouni, A. (2010) L'huile d'argan, de la nutrition à la santé. Phytothérapie, 8, 89-97. https://doi.org/10.1007/s10298-010-0538-9

[41] COI (2011) Norme commerciale applicable aux huiles d'olive et aux l'huiles de grignions d'olive.

[42] Codex (1989) Normes codex pour les huiles d'olive vierges et raffinées et pour l'huile de grignons d'olive raffinée.

[43] Tchiégang, C., Dandjouma, A., Kapseu, C. and Parmentier, M. (2005) Optimisation de l'extraction de l'huile par pressage des amandes de Ricinodendron heudelotii Pierre ex Pax. Journal of Food and Engineering, 68, 79-87.

https://doi.org/10.1016/j.jfoodeng.2004.05.025

[44] Gharby, S., Harhar, H., Bouzoubaa, Z., Asdadi, A., El Yadini, A. and Charrouf, Z. (2017) Chemical Characterization and Oxidative Stability of Seeds and Oil of Sesame Grown in Morocco. Journalof the Saudi Societyof Agricultural Science, 16, 105-111. https://doi.org/10.1016/j.jssas.2015.03.004

[45] Azhari, S., Xu, Y.S., Jiang, Q.X. and Xia, W.S. (2014) Physicochemical Properties and Chemical Composition of Seinat (Cucumis melo var. tibish) Seed Oil and Its Antioxidant Activity. Grasas y Aceites, 65, 1-9. https://doi.org/10.3989/gya.074913

[46] Borchani, C., Besbes, S., Blecker, C.H. and Attia, H. (2010) Chemical Characteristics and Oxidative Stability of Sesame Seed, Sesame Paste, and Olive Oils. Journal of Agricultural Science and Technology, 12, 585-596.

[47] Shao, D., Venkitasamy, C., Li, X., Pan, Z., Shi, J., Wang, B., Teh, H.E. and McHugh, T.H. (2015) Thermal and Storage Characteristics of Tomato Seed Oil. Journal of Food Science and Technology, 63, 191-197.

[48] Al-Farga, A., Zhang, H., Siddeeg, A., Chamba, M.V.M. and Nabil, Q.A. (2015) Physicochemical Properties, Phenolic Acids and Volatile Compounds of Oil Extracted from Dry Alhydwan (Boerhavia elegana Choisy) Seeds. Grasas y Aceites, 66, 1-9.

[49] Iskander, M.H., Hammam, A.M., Sorour, M.A. and Mehanni, A.E. (2009) Effect of Storage Period and Antioxidants Treatment on Physiochemical Characteristics and Stability of Cotton Seed and Canola Oils. Journal of Environmental Studies, 1, 55-64.

[50] Ajayi, I.A. (2010) Physicochemical Attributes of Oils from Seeds of Different Plants in Nigeria. Bulletin of the Chemistry Society of Ethiopia, 24, 145-149. https://doi.org/10.4314/bcse.v24i1.52980

[51] Oyeleke, G.O., Salam, M.A. and Adetoro, R.O. (2012) Some Aspects of Nutrient Analysis of Seed, Pulp and Oil of Baobab (Adansonia digitata L.). Journal of Environmental Science, Toxicologyand Food Technology, 1, 32-35. 
https://doi.org/10.9790/2402-0143235

[52] Pharmacopéeeuropéenne (2002) Conseil de l'Europe. 4éme édition, Strasbourg.

[53] El Antari, A., Hilal, A., Boulouha, B. and El Moudni, A. (2000) Influence of the Variety, Environment and Cultural Techniques on the Characteristics of Olive Fruits and the Chemical Composition of Extra Virgin Olive Oil in Morocco. Olivae, 80, 29-36.

[54] Tchiégang, C., Ngo Oum, M., Aboubakar Dandjouma, A. and Kapseu, C. (2004) Qualité et stabilité de l'huile extraite par pressage des amandes de Ricinodendron heudelotii (Bail.) Pierre ex Pax pendant la conservation à température ambiante. Journal of Food Engineering, 62, 69-77. https://doi.org/10.1016/S0260-8774(03)00172-9

[55] Brevedan, M.I.V., Carelli, A.A. and Crapiste, G.H. (2000) Changes in Composition and Quality of Sunflower Oils during Extraction and Degumming. Grasas y Aceites, 51, 417-423.

[56] Xu, Y.X., Hanna, M.A. and Josiah, S.J. (2007) Hybrid Hazelnut Oil Characteristics and Its Potential Oleochemical Application. Industrial Crops and Products, 26, 69-76. https://doi.org/10.1016/j.indcrop.2007.01.009

[57] Oduje, A.A., Awode, A., Edah, A. and Sagay, I. (2015) Characterization and Phytochemical Screening of n-Hexane Oil Extract from Cissus aralioides Seeds. International Journal of Scientific and Engineering Research, 6, 112-116.

[58] Rolland, Y. (2004) Antioxydants naturels végétaux. Oléagineux, Corps Gras, Lipides, 11, 419-424. https://doi.org/10.1051/ocl.2004.0419

[59] Shahidi, F. and Zhong, Y. (2005) Lipid Oxidation: Measurement Methods. In: Shahidi, F., Ed., Bailey's Industrial Oil and Fat Products, John Wiley \& Sons, Inc., Hoboken, 357-385. https://doi.org/10.1002/047167849X.bio050

[60] Judde, A. (2004) Prévention de l'oxydation des acides gras dans un produit cosmétique: Mécanismes, conséquences, moyens de mesure, quels antioxydants pour quelles applications? Oléagineux, Corps Gras, Lipides, 11, 414-418.

[61] Bhatnagar, A.S. and Gopala Krishna, A.G. (2014) Lipid Classes and Subclasses of Cold-Pressed and Solvent-Extracted Oils from Commercial Indian Niger (Guizotia abyssinica (L.f.) Cass.) Seed. Journal of the American Oil Chemists Society, 91, 1205-1216. https://doi.org/10.1007/s11746-014-2461-y

[62] Adebayo, A.W., Ogunsina, B.S. and Gbadamosi, O.S. (2015) The Effect of Cold-Pressing and Solvent Extraction on Some Characteristics of kariya (Hildergadia barteri) Seed Oil. Nutrutionand Food Science, 45, 625-633. https://doi.org/10.1108/NFS-05-2014-0048

[63] Betiku, E. and Adepoju, T.F. (2013) Sorrel (Hibiscus sabdariffa) Seed Oil Extraction Optimization and Quality Characterization. American Chemical Science Journal, 3, 449-458. https://doi.org/10.9734/ACSJ/2013/2777

[64] Lagardere, L., Lechat, H. and Lacoste, F. (2004) Détermination de l'acidité et de l'indice de peroxyde dans les huiles d'olive vierges et dans les huiles raffinées par spectrométrie proche infrarouge à transformée de Fourier. Oléagineux, Corps Gras, Lipides, 11, 70-75. https://doi.org/10.1051/ocl.2004.0070

[65] Laguerre, M., López-Giraldo, L.J., Lecomte, J., Pina, M. and Villeneuve, P. (2007) Outils d'évaluation in vitro de la capacité antioxydante. Oléagineux, Corps Gras, Lipides, 14, 278-292. https://doi.org/10.1051/ocl.2007.0140

[66] Akintayo, E.T. and Bayer, E. (2002) Characterization and Some Possible Uses of Pluketia conophora and Adenopus breviflorus Seeds and Seeds Oils. Bioresource 
Technology, 85, 95-97. https://doi.org/10.1016/S0960-8524(02)00073-1

[67] Nyakudya, T.T., Nosenga, N., Chivandi, E., Erlwanger, K.H., Gundidza, M., Gundidza, E., Magwa, M.L. and Muredzi, P. (2015) Grewia Bicolor Seed Oil: Putative Pharmaceutical, Cosmetic and Industrial Uses. South African Journal of Botany, 97, 154-158. https://doi.org/10.1016/j.sajb.2015.01.004

[68] Gecgel, U., Demirci, A.S., Dulger, G.C., Gecgel, U., Tasan, M., Arici, M. and Ay, O. (2015) Some Physicochemical Properties, Fatty Acid Composition and Antimicrobial Characteristics of Different Cold-Pressed Oils. La Rivista Italiana Delle Sostanze Grasse, 92, 187-200.

[69] Salih, N. and Yahia, E.M. (2015) Phenolics and Fatty Acids Compositions of Vitex and Baobab Seeds Used as Coffee Substitutes in Nuba Mountains, Sudan. Agriculture and Biology Journalof North America, 6, 90-93.

[70] Ranalli, A., Ferrante, M.L., De Mattia, G. and Costantini, N. (1999) Analytical Evaluation of Virgin Olive Oil of First and Second Extraction. Journal of Agricultural and Food Chemistry, 47, 417-424. https://doi.org/10.1021/jf9800256

[71] Choe, E. and Min, D.B. (2006) Mechanisms and Factors for Edible Oil Oxidation. Comprehensive Reviews in Food Scienceand Food Safety, 5, 169-186. https://doi.org/10.1111/j.1541-4337.2006.00009.x

[72] Galvano, F., La Fauci, L., Graziani, G., Ferracane, R., Masella, R., Di Giacomo, C., Scacco, A., D’Archivio, M., Vanella, L. and Galvano, G. (2007) Phenolic Compounds and Antioxidant Activity of Italian Extra Virgin Olive Oil Monti Iblei. Journal of Medicinal Food, 10, 650-656. https://doi.org/10.1089/jmf.2007.409

[73] Djeddi, S., Yannakopoulou, E., Papadopoulos, K. and Skaltsa, H. (2015) Activités anti-radicalaires de l'huile essentielle et des extraits bruts de Thymus numidicus Poiret, Algérie. Afrique Science, 11, 58-65.

[74] Merouane, A., Noui, A., Medjahed, H., Nedjari Benhadj Ali, K. and Saadi, A. (2015) Activité antioxydante des composés phénoliques d'huile d'olive extraite par méthode traditionnelle. International Journal of Biologicaland Chemical Sciences, 8 , 1865-1870. https://doi.org/10.4314/ijbcs.v8i4.45

[75] Guzmán, E., Baeten, V., Pierna, J.A.F. and García-Mesa, J.A. (2015) Evaluation of the Overall Quality of Olive Oil Using Fluorescence Spectroscopy. Food Chemistry, 173, 927-934. https://doi.org/10.1016/j.foodchem.2014.10.041 